\title{
PENGARUH MASASE EFFLURAGE PADA EXTRIMITAS BAWAH TEHADAP KECEPATAN LARI 100 METER MAHASISWA IKOR A 2013
}

\author{
Oleh \\ Rima Mediyana Sari ${ }^{1}$, Mangasi Malatua ${ }^{2}$ \\ ${ }^{1}$ Fakultas Ilmu Keolahragaan Universitas Negeri Medan \\ ${ }^{2}$ Fakultas Ilmu Keolahragaan Universitas Negeri Medan \\ Email: soberr_soul@gmail.com
}

\begin{abstract}
Abstrak
Masase effluarage adalah salah satu jenis manipulasi masase yang berfungsi untuk memperlancar aliran darah. Dalam penelitian ini bertujuan untuk mengetahui seberapa besar pengaruh masase efflurage terhadap kecepatan lari 100 meter mahasiswa Ikor A 2014. Metode penelitian ini menggunakan eksperimen dengan rancangan pretest-posttest group control. Dalam penelitian ini yang menjadi populasi adalah seluruh mahasiswa ikor A 2014 yang berjenis kelamin laki-laki yang berjumlah 23 orang. Adapun yang menjadi sampel penelitian adalah 15 orang yang diambil secara random sampling dan dibagi menjadi tiga kelompok. Prettest dan posttest berbentuk lari 100 meter dengan ini maka yang menjadi alat ukur pada penelitian ini adalah waktu (detik). Ketiga kelompok berbeda-beda perlakuan yang diberikan yakni kelompok 1). Berbaring 2). Masase Effluarage 3). Jogging masing-masing selama 10 menit. Data dianalisis menggunakan anova satu arah. Dari hasil analisis data menunjukkan $F_{\text {hitung }}=0.855$ dan $F_{\text {tabel }}=3.89$, ini berarti menunjukkan bahwa $F_{\text {hitung }}<F_{\text {tabel }}$ maka $H_{0}$ diterima dan $H_{a}$ diterima. Jadi tidak terdapat ada perbedaan kecepatan lari 100 meter antara kelompok sampel yang diberi perlakuan berbaring 10 menit, masase dan jogging selama 10 menit. Dengan demikian kesimpulan dari penelitian ini adalah "Tidak terdapat pengaruh yang signifikan masase effluarage extrimitas bawah terhadap kecepatan lari 100 meter Ikor A 2014".
\end{abstract}

Kata kunci : Masase effluarage, Lari 100 meter

\section{A. PENDAHULUAN}

Lari cepat atau sprint adalah semua perlombaan lari dimana peserta berlari dengan kecepatan maksimal sepanjang jarak yang harus ditempuh, sampai dengan jarak 400 meter masih dapat digolongkan dalam lari cepat. Menurut Muhajir (2004) sprint atau lari cepat yaitu, perlombaan lari di mana peserta berlari dengan kecepatan penuh yang menempuh jarak 100 m, 200 m, dan 400 m. Kebutuhan yang relatif penting untuk lari sprint sangat beragam bergantung pada kategori usia.

Setiap melakukan aktifitas tubuh membutuhkan energi. Semakin berat aktifitas yang dilakukan, akan semakin besar pula energi yang dibutuhkan oleh tubuh. Energi adalah kapasitas atau kemampuan untuk melakukan pekerjaan. Energi ini berupa senyawa energi yang dikenal dengan adenosine trifosfat (ATP). Proses-proses pembetukan ATP melalui (1) Sistem ATP-PC (fosfagen), (2) Sistem asam laktat dan 
(3) Sistem aerobik. Estimasi waktu dan energi yang digunakan untuk melakukan aktiftas adalah (1) ATP : 1 detik, (2) ATP-PC : aktifitas antara 15-20 detik, (3) ATPPC-LA : aktifitas antara 20 detik - 2 menit dan (4) Sistem aerob (oksigen): aktifitas lebih dari 2 menit. Lari 100 meter dilakukan dengan intensitas yang maksimal, dengan waktu kurang dari 15 detik. Oleh karena itu sistem energi yang digunakan adalah ATPPC. Sistem ATP-PC atau sistem fosfagen merupakan sumber energi utama untuk aktifitas yang berintensitas sangat tinggi, seperti lari 100 meter

Gerakan-gerakan dalam atletik adalah gerakan yang dilakukan manusia seharihari. Atletik diartikan sebagai aktivitas jasmani atau latihan fisik, berisikan gerakangerakan alamiah dasar atau wajar seperti jalan, lari, lompat dan lempar. Karena atletik merupakan gerakan yang dilakukan manusia seharihari, maka dalam hidupnya manusia tentu pernah melakukan gerakan lari, jalan, lompat dan lempar. Olahraga atletik telah dikenal sejak lama diberbagai bangsa, kemudian/ berkembang dengan kondisi serta peningkatan dalam sarana, teknik dan /gaya. Dengan /demikian dapat dikemukakan,bahwa atletik adalah salah satu cabang yang dipertandingkan atau diperlombakan yang meliputi atas nomor-nomor jalan, lari, lompat dan lempar. Atletik merupakan dasar untuk melakukan bentuk-bentuk gerakan yang terdapat di dalam cabang olahraga yang lainnya/Nomor lari berdasarkan jarak yang ditempuh dibedakan menjadi: a) lari jarak pendek sprint mulai dari 60 sampai 400 meter, b) lari jarak menengah (middle distance) mulai dari jarak 800 meter sampai 1500 meter, dan c) lari jarak jauh (long distance)mulai dari jarak 3000 meter sampai dengan 42,195 km (marathon) menurut Eddy Purnomo, ( $2007: 1$ ).

Start adalah suatu persiapan awal seorang pelari akan melakukan gerakan lari. Untuk nomor jarak pendek star yang dimpakai adalah start jongkok (Crouch Start). Tujuan utama start dalam lari jarak pendek adalah untuk mengoptimalisasikan pola lari percepatan. Aba-aba lari sprint meliputi bersedia, siaap, yaak atau door bunyi pistol. Setelah starter memberikan aba-aba "Bersedia", maka pelari akan menempatkan kedua kaki dalam menyentuh blok star bagian depan dan belakang, lutut kaki belakang diletakan di tanah, terpisah selebar bahu lebih sedikit. Jari-jari tangan membentuk huruf $\mathrm{V}$ terbalik, dan kepala dalam keadaan datar dengan punggung, sedangkan pandangan mata menatap lurus ke bawah. Pada saat aba-aba "Siaaap" pelari menempatkan posisi lutut ditekan ke belakang, lutut kaki depan ada dalam posisi membentuk sudut siki-siku 
900 sedangkan lutut kaki belakang membentuk sudut antara 1200-1400. Posisi pinggang sedikit diangkat tinggi dari bahu, tubuh sedikit condong ke depan, serta bahu sedikit lebih maju ke depan dari kedua tangan ( Heryana,2010 : 18).

Dalam berlari juga dibagi menjadi beberapa tahapan (Purnomo 2007: 33). Pertama tahap topang terdiri dari topang depan dan satu tahap dorong. Kedua tahap melayang yang terdiri dari tahap ayun ke depan dan satu tahap pemulihan (recovery). Tahap topang bertujuan untuk memperkecil hambatan saat menyentuh tanah dan memaksimalkan dorongan ke depan. Sifat-sifat teknisnya mendarat pada telapak kaki, lutut kaki topang bengkok harus minimal pada saat amortasi, kaki ayun dipercepat, pinggang, sendi lutut dan mata kaki dari kaki topang harus diluruskan kuat-kuat pada saat bertolak, paha kaki ayun naik dengan cepat ke suatu posisi horisontal. Phase layang bertujuan untuk memaksimalkan dorongan ke depan dân untuk mempersiapkan suatu penempatan kaki yang efektif saat menyentuh tanah. Sifat-sifat teknisnya lutut kaki ayun bergerak ke depan dan ke atas, lutut kaki topang bengkok dalan phase pemulihan, ayunan lengan aktif namun relaks, berikutnya kaki topang bergerak ke belakang.

Sebuah perlombaan diakhiri dengan finish. Hal ini juga berlaku pada lari $100 \mathrm{~m}$ untuk Mahasiswa ilmu keolahragaan. Untuk memenangkan sebuah perlombaan seorang pelari harus menguasai teknik start, teknik lari $100 \mathrm{~m}$, dan teknik finish. Walaupun waktu antara pelari hanya beberapa detik. Pelari yang menyentuh finish pertama kali yang menang. Menurut khomsin (2005 : 42) teknik memasuki garis finish dapat melalui tiga cara :

* Lari terus tanpa mengubah sikap

* Dada dicondongkan kedepan dengan kedua tangan diayun kebelakang, dan

- Dada diputar dengan mengayunkan tangan ke depan sehingga bahu sebelah maju kedepan.

\section{Ektrimitas Bawah}

Panjang tungkai adalah jarak vertikal antara telapak kaki sampai dengan pangkal paha yang diukur dengan cara berdiri tegak. Panjang tungkai sebagai bagian dari postur tubuh memiliki hubungan yang sangat erat kaitannya sebagai penolak disaat melakukan lari dan lompatan. Panjang tungkai sebagai salah satu anggota gerak bawah memiliki peran penting dalam unjuk kerja olahraga khususnya cabang olahraga atletik nomor lari 100 meter. Sebagai anggota gerak bawah, panjang tungkai berfungsi sebagai penopang 
gerak anggota tubuh bagian atas, serta penentu gerakan baik dalam berjalan, berlari, melompat. Panjang tungkai melibatkan tulang-tulang dan otot-otot pembentuk tungkai baik tungkai bawah dan tungkai atas.

Tulang-tulang pembentuk tungkai meliputi tulang-tulang kaki, tulang tibia dan fibula, serta tulang femur (Reven, 1981:14). Seperti defininya tulang adalah penyangga / penopang tubuh dan terdiri atas kalogen, suatu protein yang berisi kalsium fosfat dan mineral yang memerikan kekuatan untuk menyangga seluruh organ tubuh. Ada berbagai jenis tulang diantaranya adalah tulang panjang, tulang pipih, dan tulang ireguler.

\section{Sistem Energi}

Energy adalah syarat penting untuk aktivitas fisik selama berlatih atau bertanding. Energy berasal dari makanan yang kita makan sehari-hari, tujuan makan selain untuk menghilangkan rasa lapar adalah untuk pertumbuhan dan mengganti sel-sel yang rusak.

Dalam melakukan ativitas sehari-hari//apapun bentuknya tubuh pasti memerlukan energy. Energy adalah kemamphan uhtuk melakukan kerja. Berdasarkan system energy predominan, maka/latihan dibagi menjadi dua bentuk latihan yaitu latihan anaerobic dan aerobic. Latihan anaerobic adalah latihan yang menggunakan energy dengan system ATP-PC (phosphogen syste,) an glikolisis anaerobi (lactacid acid system), dan latihan aerobic adalah latihan yang menggunakan system glikolisis aerobic ( aerobic glicolysis).

\section{Metabolisme Aerobik}

Selain tidak menimbulkan kelelahan karena tidak menghasilkan asam laktat, metabolism aerobik juga sangat efisien dalam pembentukan ATP. Ini bisa dilihat dari besarnya jumlah unit ATP yang dihasilkan selama proses metabolism aerobic yaitu sejumlah 36. Namun untuk mendapat ATP sebesar itu diperlukan beberapa reaksi kimia yang terjadi yaitu glikolisis aerobik serta reaksi yang terjadi didalam mitokondria berupa siklus krebs ( Tricarboxyclic acid) dan sistem transport electron (Electron Transport System).

4. Metabolisme Anaerobik

Arti dari metabolisme anaerobik adalah metabolisme yang terjadi tanpa oksigen. Sumber tenaga yang diperoleh melalui metabolisme anaerobik merupakan konsekuensi dari aktifitas tubuh pada intensitas tinggi yang membutuhkan pasokan energi segera. 
Walaupun tersedia oksigen dalam darah dan diudara. Tetapi metabolisme secara aerobik terlalu lama waktunya sehingga tubuh menggunakan jalur anaerobik sebagai cara mensintesis ATP. Ini dilakukan karena dalam proses metabolisme anaerobik ATP dapat dihasilkan lebih cepat dibandingkan dengan proses aerobik. Dalam proses metabolisme anaerobik juga terdapat dua sistem energi yang bekerja, yaitu ATP-PC dan sistem glikolisis anaerobic.

5. System Asam laktat

System anaerobic selain dari resintesis ATP didalam otot, adalah glikolisis anaerobic, yang melibatkan pemecahan tidak sempurna dari salah satu bahan makanan yaitu karbohidrat (gula), menjadi asam laktat (karena itu dinamakan asam laktat). Di dalam tubuh, semua karbohidrat dikonversi menjadi gula sederhana yaitu glukosa, yang segera dapat dipergunaan dalam bentuk glukosa, di simpan di dalam hati dan otot sebagai glikogen untuk dipergunakan kemudian. Asam laktat adalah hasil dari glikolisi anaerobik (Junusul Hairy, 1989:77).

System glikolisis anaerobic atau system asam laktat inilebih rumit dibandingkan dengan system ATP-PC. Proses pembentukan energy melalui system asam laktat dan memerlukan 12 macam reaksi kimia yang beraturan, sehingga pembentukan energy berjalan lebih lambat jika dibandingkan dengan system ATP-PC. System asam laktat mengubah glukosa dan glikogen pada sitoplasma sel otot menjadi energy dan asam laktat.

Proses glikolisis anaerobic memerlukan 12 macam reaksi kimia secara berurutan, sehingga energy yang terbentuk melalui system energi ini berlangsung lebih lambat dibandingkan dengan system ATP-PC yang hanya membutuhkan 2 reaksi kimia saja. Jadi, untuk kontraksi otot yang sangat cepat digunakan ATP-PC, sedangkan untuk kontraksi otot yang cepat digunakan system anaerobic. Proses ini berlangsung tanpa adanya oksigen, sehingga asam laktat merupakan produk akhir dari metabolisme glukosa dengan system metabolisme anaerobic. Ciri-ciri dari system glikolisis anaerobic adalah sebagai berikut: (1) menyebabkan terbentuknya asam laktat yang dapat menyebabkan kelelahan, (2) tidak membutuhkan oksigen, (3) hanya menggunakan system enrgi karohidrat (glikogen dan glukosa), dan (4) energy yang dilepaskan hanya cukup untuk resitensis ATP dalam jumlah yang sedikit. 
6. Recovery (Pemulihan)

Dalam olahraga faktor pemulihan memegang peranan yang sangat penting. Setelah melakukan pertandingan akan menyebabkan cadangan energi dalam tubuh aktivitas intensity kelelahan. Pemulihan denyut nadi adalah pemulihan dimana denyut nadi kembali kedenyut nadi awal setelah melakukan kegiatan fisik (Paidin,1990). Proses pulih asal adalah multi-dimensional dan tergantung dari berbagai macam faktor. Recorvery dibagi menjadi dua yaitu ; recovery penuh dan recovery tidak penuh. Interval recovery tidak penuh adalah singkat (sampai kira-kira 90 detik) dan hanya tahap recovery yang pertama. Interval recovery penuh adalah lama, dimana waktu recovery berlangsung lebih lama dan digunakan untuk kompetisi-kompetisi dan latihan kecepatan reaksi (Bompa, 2009)

Pemulihan aktif adalah apabila setelah berolahråga, dilanjutkan dengan latihan pada kuantitas dan kualitas yang lebih ringan hingga kadar metabolit kembali kebatas normal. "Prinsip recovery yang dipercepat (D.Martin,59 dalam/Harsono) dikenal dengan recovery aktif, yang menyebabkan pemulthan (restorasi) fungsional organism secara lebih cepat. Recovery aktif jtu dapat ditarapkan selama metode latihan sirkuit atau antara unit-unit latihan yang mengikuti dengan singkat satu unit setelah unit lainnya. Recovery aktif adalah menguntungkan, jika pembebanannya sebelumnya tidak sangat melelahkan.

7. Massage

Manipulasi adalah cara pengangan atau grip, yaitu jenis perlakuan yang diberikan oleh tangan, lengan atau bagian tubuh masseur atau massage lainnya untuk memberikan perlakuan massage pada daerah-daerah tubuh tertentu serta untuk memberikan pengaruh yang positif. Setiap massage pasti menggunakan manipulasi dalam melakukan aktivitasnya, banyak jenis-jenis manipulasi yang kita kenal termasuk istilah yang diberikan serta tujuan yang akan dicapai (Mashoed,1997).

8. Efflurage (menggosok)

Adalah gerakan urut mengusap secara ritmis atau berirama dan berurutan dari arah bawah ke atas. Efflurage dilakukan dengan telapak tangan dan jari merapat. Pada saat tangan bergerak meluncur diatas permukaan tubuh, grakan ini harus mengalir tanpa terputus. Gerakan effleurage dilakukan dengan tekanan ringan, dan dapat kembali ke posisi awal, gerakan harus dilakukan dengan usapan yang lebih ringan dan 
menyenangkan. Tujuan dari effleurage adalah meratakan minyak pada permukaan tubuh, membantu memperlancar aliran darah dan meningkatkan suhu kulit. Gerakan effleurage biasanya dilakukan untuk mengawali dan mengakhiri masase, serta gerakan transisi antara gerakan yang satu ke gerakan berikutnya (Purnomo, 1994).

\section{B. METODE PENELITIAN}

Penelitian ini dilaksanakan di Stadion Universitas Negeri Medan Jalan William Iskandar, Pasar V Medan Estate, Kec. Medan Tembung, Sumatera Utara, dengan jumlah sampel sebanyak 15 orang. Jenis penelitian yang digunakan dalam penelitian ini adalah penelitian eksperimen. Rancangan penelitian yang digunakan pada penelitian ini adalah pretest-posttest group control. Kelompok sampel dibagi tiga kelompok, kelompok pertama adalah kelompok kontrol yang diberikan pretest berupa lari sprint 100 meter lalu berbaring selama 10 menit tanpa diberikan perlakuan selanjutnya sampel melakuakan post test lari sprint 100 meter. Kelompok kedua adalah kelompok ekperiment terlebih dahulu sampel melakâkân pretest dengân/berlarisprint 100 meter selanjutnya diberikan perlakuan masase efflurage selama 10 menit setelah itu sampel melakukan postest lari sprint 100 meter. Kelompok ketiga hampir sama dengan kelompok dua, dimana sampel terlebih dahulu melakukan pretest lari sprint 100 meter selanjutnya diberikan perlakuan jongging selama 10 menit dan selanjutnya sampel melakukan postest lari sprint 100 meter.

Rancangan yang akan dilakukan peneliti dalam penelitian ini adalah sampel akan dibagi menjadi tiga kelompok menjadi kelompok 1, kelompok 2, dan kelompok 3 dengan cara Random Sampling pupolasi dibagi secara acak dan setiap kelompok memiliki 5 sampel sehingga keseluruhan sampel menjadi 15 sampel pada ketiga kelompok penelitian ini. Kelompok 1 adalah kelompok kontrol dimana sampel terlebih dahulu melakukan pretest lari 100 meter setelah pretest sampel beraring selama 10 menit dan dilanjutkan postest sprint 100 meter setiap sampel sprint 100 meter diambil waktunya sebagai alat ukur dalam penelitian ini. Kelompok 2 yaitu kelompok ekperimen dimana sampel terlebih dahulu melakuakan pretest sprint 100 meter setelah sprint sampel langsung diberikan perlakuan masase efflurage selama 10 menit selanjutnya sampel melakukan postest sprint 100 meter setiap sampel melakukan sprin 100 meter diambil waktunya sebagai alat ukur dalam penelitian ini. Kelompok 3 yaitu kelompok ekperimen dimana sampel terlebih dahulu melakuakan pretest sprint 100 
meter setelah sprint sampel langsung diberikan perlakuan jogging selama 10 menit selanjutnya sampel melakukan postest sprint 100 meter setiap sampel melakukan sprin 100 meter diambil waktunya sebagai alat ukur dalam penelitian ini.

\section{Prosedur Penelitian}

1. Pada awalnya tester akan memberikan aba-aba "BERSEDIA",masing-masing testee bersiap dengan berdiri dibekang garis start maka testee akan menempatkan kedua kaki dalam menyentuh blok star bagian depan dan belakang, lutut kaki belakang diletakan di tanah, terpisah selebar bahu lebih sedikit. Jari-jari tangan membentuk huruf $\mathrm{V}$ terbalik, dan kepala dalam keadaan datar dengan punggung, sedangkan pandangan mata menatap lurus ke bawah.

2. Pada saat aba-aba "Siaaap" testee menempatkan posisi lutut ditekan ke belakang, lutut kaki depan ada dalam posisi membentuk sudut siki-siku 900 sedangkan lutut kaki belakang membentuk sudut antara 1200-1400. Posisi pinggang sedikit diangkat tinggi dari bahu, tubuh sedikit condong ke depan, serta bahu sedikit lebih thaju ke depan dari kedua tangan.

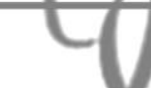

3. Gerakan yang akan dilakukan pelari setelah aba-aba "Yaak" adalah badan diluruskan dan diangkat pada saat kedua kaki menolak/menekan keras pada start blok. Kedua tangan diangkat dari tanah bersamaan untuk kemudian diayun bergantuan. Kaki belakang mendorong kuat/singkat, dorongan kaki depan sedikit kaki belakang diayun ke depan dengan cepat sedangkan badan condong ke depan, lutut dan pinggang keduanya diluruskan penuh pada saat akhir dorongan

Teknik analisis data yang digunakan yaitu: Rata-rata,hitung (Mean), Uji Varian, Standart Deviasi, Uji normalitas menggunakan rumus kuadrat (Chi-square). Data yang diperoleh sebagai skor individu dari hasil tes selanjutnya diolah dengan menggunakan prosedur statistik untuk membuktikan apakah hipotesis yang telah diajukan dalam penelitian ini dapat diterimam atau ditolak.

\section{HASIL DAN PEMBAHASAN}

\section{Hasil Penelitian}

Dari hasil uji anava satu jalur menunjukkan bahwa $F_{\text {hitung }}<\mathrm{F}_{\text {tabel }}$ maka $\mathrm{H}_{0}$ diterima sehingga tidak ada pengaruh yang signifikan dari ketiga kelompok berbaring, masase, dan jogging terhadap kecepatan lari 100 meter.. Dengan kata lain masase 
effluarage tidak memberikan pengaruh yang signifikan terhadap kecepatan lari 100 meter.

\section{Pembahasan Hasil Penelitian}

Hasil analisa data maupun pengujian hipotesis yang telah dikemukakan menunjukkan bahwa hipotesis yang diajukan ditolak. Namun hasil ini masih perlu pembahasan lebih lanjut untuk meberikan interpretasi yang lebih mendalam tentang hasil penelitian yang diperoleh dikaitkan dengan teori-teori maupun kerangka berfikir yang telah dikemukakan sebelumnya.

Peneliitian ini dilakukan untuk mengetahui pengaruh masase effluarage extrimitas bawah terhadap kecepatan Jari 100 meter pada pemberian perlakuan berbaring, masase effluarage, dan joging. Dari hasil penelitian menunjukkan tidak ada perbedaan pengaruh yang signifikan ke tiga variabel tersébut.

Dari hasil uji Anava Satu Jalur menunjukkan bahwa tidak ada pengaruh yang signifikan hasil pemberian posttest kelompok berbaring, masase, dan jogging terhadap kecepatan lari 100 meter dimana hasil analisa ini dirujuk/d/dukung oleh penelitian.

Atletik merupakan cabang olahraga yang paling tua dan merupakan induk dari semua cabang olahraga yang gerakannya merupakan ragam dan pola gerak dasar hidup manusia (Eddy Purnomo, 2007: 3). Lari 100 meter dilakukan dengan intensitas yang maksimal, dengan waktu kurang dari 15 detik. Oleh karena itu sistem energi yang digunakan adalah ATP-PC. Sistem ATP-PC atau sistem fosfagen merupakan sumber energi utama untuk aktifitas yang berintensitas sangat tinggi, seperti lari 100 meter.

Setiap melakukan aktifitas tubuh membutuhkan energi. Semakin berat aktifitas yang dilakukan, akan semakin besar pula energi yang dibutuhkan oleh tubuh. Energi adalah kapasitas atau kemampuan untuk melakukan pekerjaan. Energi ini berupa senyawa energi yang dikenal dengan adenosine trifosfat (ATP). Proses-proses pembetukan ATP melalui (1) Sistem ATP-PC (fosfagen), (2) Sistem asam laktat dan (3) Sistem aerobik. Estimasi waktu dan energi yang digunakan untuk melakukan aktiftas adalah (1) ATP : 1 detik, (2) ATP-PC : aktifitas antara 15-20 detik, (3) ATP-PC-LA : aktifitas antara 20 detik - 2 menit dan (4) Sistem aerob (oksigen): aktifitas lebih dari 2 menit.

Sistem metabolisme energi untuk menghasilkan ATP dapat berjalan secara aerobik (dengan oklsigen) dan secara anaerobik (tanpa oksigen). Kedua proses ini dapat 
berjalan secara simultan didalam tubuh saat berolahraga. Adenosine triphosphate (ATP) merupakan sumber energi yang terdapat didalam sel-sel tubuh terutama sel otot yang dipergunakan untuk aktifitas otot. Menurut Fox (1993) dalam tesis Novita Sari Harahap menyatakan bahwa aktifitas fisik berdasarkan sumber tenaganya atau pebentukan ATP melalui tiga sistem yaitu 1) Sistem aerobik, 2) Sistem glikolisis anaerobik, 3) Sistem ATP-Creatin Phospat. Estimasi waktu dan energi yang digunakan untuk melakukan aktiftas adalah (1) ATP : 1 detik, (2) ATP-PC : aktifitas antara 15-20 detik, (3) ATPPC-LA : aktifitas antara 20 detik - 2 menit dan (4) Sistem aerob (oksigen): aktifitas lebih dari 2 menit. Terdapat 2 macam sistem peakaian energi aerobik yang dapat menghasilkan ATP selama latihan yaitu 1) sistem ATP-PC 2) sistem asam laktat.

Glukosa dari glikogen otot dipecah menjadi asam laktat. Sementara itu, penumpukan asam laktat akan menghambat glikolisis, sehingga timbul kelelahan otot. Melalui proses pembentukan asam laktat dar 1 mol $/ 180$ gram) glikogen otot dihasilkan 3 ATP. Kadar asam laktat yang lebih dari $6 / \mathrm{mmol} / \mathrm{L}$ sudah cakup tinggi untuk berkontribusi terhadap terjadinya kelelahan (Totot dkk, 2012).

Dari hasil penelitian yang dilakukan terhadap 15 mahasiswa Ilmu Keolahragaan angakatan 2014 kelas A dapat disimpulkan bahwa kecepatan lari 100 meter antara perlakuan berbaring, masase, dan jogging tidak berbeda ditaraf nyata signifikan dikarenakan ada beberapa faktor yang menyebabkan terjadi hal tersebut yaitu:

1. Jumlah sampel sedikit

2. Sampel mengalami kelelahan sebelum melakuakan penelitian

3. Sampel kurang serius dalam melakukan prosedur penelitian

Secara ringkas terlihat perbedaan pretest dan postets kecepatan lari 100 meter pada kelompok masase, kelompok jogging, dan kelompok berbaring. Namun setelah pengolahan data secara statistik dapat disimpulkan bahwa tidak ada pengaruh yang signifikan masase effluarage extrimitas bawah terhadap kecepatan lari 100 meter.

\section{KESIMPULAN}

Masase effluarage pada extrimitas bawah selama 10 menit tidak memberikan pengaruh terhadap kecepatan lari 100 meter mahasiswa Ikor A 2014. 


\section{Daftar Pustaka}

Adityawarman. (2016). Pengaruh Effleurage dan Friction Terhadap Penurunan Kadar Asam Laktat Pelari Sprint 400 Meter. Surakarta. Universitas Muhammadiyah

Afriwardi. (2008). Pengaruh Pemulihan Aktif dan Pemulihan Pasif terhadap lamanya Perubahan Kadar Asam Laktat Darah. Padang. ANDALAS

Andriawan, Anang. (2009). "Pengaruh Mekanis masase lokal Extrimitas Bawah Terhadap Kemampuan Daya Ledak Otot Tungkai Pada Pemain Bola Voli”. Skripsi tidak diterbitkan. Surabaya: Universitas Negeri Surabaya

Ditjen Pendidikan Luar Sekolah dan Olahraga, (1980). Sport Masase. Jakarta: Depdikbud.

Djumijar. (2007). Atletik dan Lari Sprint. Banjarnegara

Giriwijoyo,dkk. (2012). Ilmu Faal Olahraga, Bandung : PT Remaja Rosdakarya

Hermawan. (2015). Perbandingan Pengaruh Sport Massage dan Swedish Massage terhadap perubahanDenyut Nadi dan Frekuensi Pernafasan. Yogyakarta

Janssen. (2012). Latihan Laktat Denyut Nadi. Jakarta : Grafiti

Junusul Hairy. (1989). Fisiologi Olahraga jilid 1.Padang

Prayogi Guntara. (2014). Penelitian Recovery Aktif dengan Recovery Pasif Terhadap Penurunan Kadan Asam Laktat. UPI

Purnomo. (2015). Perubahan/Kadar Laktat_Darah Akibat Manipulasi Sport Massage Pada Latihan Anaerob. Semarang. UNNES

Roepajadi, Joesoef. (2010). Masase Dasar. Universitas Negeri Surabaya.

Sri Rahajoe. (1993). Disproporsi Perubahan Kadar Glukosa Asam Laktat dan Hemoglobin Darah Sebagai Parameter Uji Kinerja Fisik. Yogyakarta. Universitas Gajah Mada

Sumarsono. (2013). Pengaruh Mekanisme Massage local Extrimitas Bawah sebagai Pemulihan Pasif Terhadap Kecepatan Lari. Surabaya. UNESA

Widiyanto. (2016). Latihan Fisik dan Laktat. FIK UNY

Warih Anjari. (2016). Perbedaan Pengaruh Circulo Massage dan Contrasbath terhadap Kadar Asam Laktat. Surakarta. Universitas Sebelas Maret

Wiltshire, E. V., Dkk. (2010). Massage Impairs Postexercise Muscle Blood Flow And "Lactic Acid" Removal. Canada. School Of Kinesiology and Health Studies, Queen's University, Kingston, Ontario. 